\title{
PERAN KEPEMIMPINAN TRANSFORMASIONAL DAN KNOWLEDGE SHARING DALAM MENSTIMULASI PERILAKU INOVATIF DI INSTITUSI PENDIDIKAN
}

\author{
Agi Syarif Hidayat \\ Universitas Swadaya Gunung Jati \\ agisyarif.jibm@gmail.com \\ Rofi Rofaida \\ Universitas Pendidikan Indonesia \\ rofi.rofaida@upi.edu
}

Abstract

\begin{abstract}
Human resources are the main production factors in implementing organizational innovation, so organizations need to encourage employees to have innovative behavior at work. Innovative behavior is not something that is genetically inherited, but something that can be learned and applied to employees in the organization. This research explores the influence of transformational leadership and knowledge sharing on innovative behavior. The research method used is a quantitative method. The population in this study were lecturers at 3 universities in the city of Cirebon. The number of samples in this study were 86 respondents. Data collection using a questionnaire instrument. Analysis of research data using multiple regression. The results showed that transformational leadership and knowledge sharing have a positive and significant influence on innovative behavior. In this study the knowledge sharing variable has a more dominant contribution compared to the transformational leadership variable to manage employee innovative behavior.
\end{abstract}

Keywords: transformational leadership; knowledge sharing; innovative behavior; university.

\section{PENDAHULUAN}

Persaingan dalam industri pendidikan saat ini semakin ketat, salah satu hal yang harus dilakukan oleh setiap institusi pendidikan adalah inovasi (Nurjanah, 2015). Inovasi yang dilakukan secara terencana dan bekesinambungan akan menghasilkan produk dan jasa yang berkualitas, hal ini akan berdampak pada meningkatnya daya saing organisasi serta dapat menjamin keberlangsungan organisasi dalam persaingan yang semakin ketat (Dewanto \& Fasial, 2017). Kajian mengenai inovasi dalam organisasi tidak bisa dilepaskan dari sudut pandang sumber daya manusia, karena salah satu faktor produksi utama yang melaksanakan proses inovasi dalam organisasi adalah sumber daya manusia (Muliawaty, 2019). Berkaitan dengan proses inovasi dalam industri pendidikan khususnya pendidikan tinggi, dosen adalah salah satu motor utamanya (Muhtarom, 2015).

Dosen merupakan pendidik yang memiliki tiga fungsi utama yaitu pengajaran, penelitian serta pengabdian kepada masyarakat, ketiga hal tersebut merupakan pekerjaan konseptual yang membutuhkan kemampuan inovasi tinggi. Seoarang dosen idealnya memiliki perilaku yang inovatif dalam bekerja agar mampu melaksanakan pekerjaannya dengan optimal. Perilaku inovatif didefinisikan sebagai aktivitas individu yang berorientasi pada penciptaan, pengenalan dan aplikasi dari sesuatu yang dianggap baru serta memberikan keuntungan bagi organisasi (Kleysen \& Street, 2011).

Pada awalanya perilaku inovatif diduga sebagai hal yang bersifat genetis, namun hasil penelitian Dyer, Gregersen, \& Christensen (2011) menunjukkan bahwa perilaku inovatif merupakan sebuah hal yang bisa dilatih dan dipengaruh oleh faktor-faktor tertentu. Salah satu determinan yang dianggap dominan dalam mempengaruhi perilaku inovatif karyawan yaitu kepemimpinan transformasional. Pemimpin yang transformatif mampu mendapatkan kepercayaan, kesetiaan, dan rasa hormat yang tinggi dari anggotanya, bahkan anggota dalam organisasi dengan sukarela berbuat lebih dari apa yang harusnya mereka lakukan (Avolio \& Bass, 1995). Kresnandito (2012) menjelaskan bahwa perilaku inovatif dipengaruhi oleh persepsi kepemimpinan transformasional. 
Faktor lainnya yang diprediksi dapat meningkatkan perilaku inovatif adalah knowledge sharing. Knowledge sharing merupakan proses pertukaran pengetahuan antar indivdu dalam organisasi yang memungkinkan terciptanya pengetahuan bahkan solusi baru dari permasalahan yang ada (De Vries, Van den Hooff, \& De Ridder, 2006). Hasil penelitian terdahulu mengidentifikasi peran knowledge sharing dalam membangun perilaku inovatif karyawan. Mura, Lettieri, Radaelli, \& Spiller (2013), menunjukkan bahwa knowledge sharing memiliki pengaruh positif terhadap perilaku inovatif khususnya dalam proses mempromosikan serta mengaplikasikan ide ide baru.

Tujuan penelitian ini adalah untuk mengetahui pengaruh kepemimpinan transformasional dan knowledge sharing terhadap pembentukan perilaku inovatif karyawan. Hasil penelitian ini diharapkan dapat mengkonfirmasi hasil penelitian terdahulu mengenai perilaku inovatif serta dapat menjadi masukan bagi pengambil keputusan dalam lingkup perguruan tinggi dalam proses pengembangan perilaku inovatif dosen.

\section{KAJIAN PUSTAKA DAN PENGEMBANGAN HIPOTESIS}

\section{Kepemimpinan Transformasional}

Burns (1978) merupakan salah satu pakar yang mempromosikan konsep kepemimpinan transformasional. Pemimpin transformatif adalah mereka yang dapat mempengaruhi pengikut mereka dengan meningkatkan tujuan konvensional dan membantu mereka meningkatkan mereka kepercayaan diri di tempat kerja (Bass, Waldman, \& Avolio, 1987). Kepemimpinan trasnformasional diidentifkasi melalui: (1) idealized influence yang merupakan kharisma yang dimiliki oleh seorang pemimpin yang membuatnya dijadikan panutan oleh anggota organisasi; (2) inspirational motivation yaitu kemampuan seoarang pemimpinan untuk memotivasi anggota serta memberi inspirasi bagi anggota organisasi dalam mencapai tujan bersama; (3) intellectual stimulation merupakan karakter pemimpin transformatif berupaya mendorong bawahan untuk memikirkan inovasi, kreatifitas metode atau caracara baru dalam mencapai tujuan; (4) individual consideration merupakan kemampuan pemimpin untuk mengidentifikasi, memahami, dan menangani kebutuhan anggota serta memperlakukan mereka dengan baik (Bass \& Riggio, 2006).

Teori kepemimpinan transformasional merupakan salah satu teori kepemimpinan yang populer, karena pengaruhnya yang besar terhadap kemajuan organisasi. Pemimpin yang transformatif mampu membuat karyawan mengutamakan kepentingan organisasi diatas kepentingan pribadi dan memiliki komitmen yang kuat untuk mencapai visi organisasi (Hansen \& Pihl-thingvad, 2019). Hal positif tersebut pada akhirnya akan berkorelasi positif dengan kinerja individu dan organisasi (Chen, Tang, Jin, Xie, \& Li, 2014; Dvir, Eden, Avolio, \& Shamir, 2002)

\section{Knowledge Sharing}

Salah satu aset penting organisasi yang jarang disadari adalah pengetahuan, akan tetapi memiliki pengetahuan saja tidak cukup, diperlukan mekanisme lebih lanjut untuk membuat pengetahuan itu menjadi lebih berguna bagi organisasi, salah satu aktivitas vital dalam menjaga dan mengembangkan pengetahuan adalah perilaku knowledge sharing. Berbagai pengetahuan merupakan interaksi sosial dalam hal pertukaran pengetahuan, pengalaman, dan keterampilan karyawan melalui seluruh departemen atau organisasi (Lin, 2007). Knowledge sharing juga dapat diartikan sebagai proses di mana individu saling bertukar pengetahuan serta berusaha menciptakan pengetahuan baru dari hasil pertukaran pengetahuan tersebut (De Vries et al., 2006). Melalui kegiatan knowledge sharing, pengetahuan yang dimiliki oleh masing-masing individu dapat dibagikan kepada anggota organisasi lainnya, sehingga pengetahuan tersebut menjadi pengetahuan organisasi (Orces, Kim, \& Lee, 2005).

Terdapat dua kegiatan penting dalam proses knowledge sharing yaitu menyumbangkan pengetahuan dan mengumpulkan pengetahuan (De Vries et al., 2006). Dalam aktivitas menyumbangkan pengetahuan, para individu mengkomunikasikan modal intelektual atau pengetahuan pribadi mereka kepada orang lain, sementara dalam aktivitas pengumpulan informasi ditandai dengan adanya proses konsultasi dengan rekan kerja untuk mendorong berbagi modal intelektual meraka. Proses knowledge sharing yang ideal setidaknya menunjukkan adanya keseimbangan antara proses donating dan 
Agi Syarif Hidayat \& Rofi Rofaida. Peran Kepemimpinan Transformasional dan Knowledge Sharing dalam Menstimulasi Perilaku Inovatif di Institusi Pendidikan

collecting pengetahuan, karena apabila hal itu tidak terjadi maka akan merugikan salah satu pihak, terutama pihak yang hanya memberi pengetahuan, tanpa dapat mengumpulkan pengetahuan.

\section{Perilaku Inovatif}

Perilaku inovatif merupakan perilaku individu yang bertujuan untuk mengeksplorasi dan mempromosikan ide, proses, produk, atau prosedur baru dan berguna (Jong \& Hartog, 2010). Perilaku inovatif dapat diartikan juga sebagai aktivitas individu yang berorientasi pada penciptaan, proses dan implementasi ide-ide yang berkaitan dengan produk, teknologi, prosedur, atau proses kerja yang relatif baru dengan tujuan untuk meningkatkan efektivitas dan pencapaian organisasi (Bos-nehles \& Veenendaal, 2019).

Jong \& Hartog (2010) menjelaskan bahwa terdapat empat dimensi dalam kajian perilaku inovatif yaitu sebagai berikut. (1) Idea exploration, merupakan proses yang dilakukan untuk mencari peluang untuk memperbaiki kondisi atau ancaman yang membutuhkan respons segera. Idea exploration tergambar dari upaya untuk mencari peluang untuk meningkatkan kualitas produk, layanan maupun proses kerja dengan pendekatan yang berbeda. (2) Idea generation, merupakan proses yang dilakukan untuk menghasilkan gagasan-gagasan baru berdasakan exsplorasi peluang dan ancaman yang ada. (3) Idea Championing, adalah upaya yang dilakukan untuk mempromosikan ide inovasi kepada orang lain dan meyakinkan orang untuk melaksanakan inovasi tersebut. (4) Idea implementation, adalah upaya yang dilakukan untuk mengimplementasikan ide yang sudah diajukan serta bertanggungjawab dalam pelaksanaan inovasi tersebut.

Perilaku inovatif merupakan perilaku positif yang ditujukan karyawan ditempat kerja, perilaku positif ini memiliki korelasi positif dengan output inovasi (Lee \& Hong, 2014), berkontribusi dalam meningkatkan kinerja organisasi (Leong \& Rasli, 2014; Yuan \& Woodman, 2010), serta berdampak pada keberlangsungan organisasi (Khodakarami \& Zakaria, 2015; Taherparvar, Esmaeilpour, \& Dostar, 2014).

\section{Hubungan antar Variabel}

Terdapat beberapa hasil penelitian yang menjelaskan dengan lebih spesifik kontribusi kepemimpinan transformasional terhadap peningkatan perilaku inovatif karyawan. Kepeimpinan transformasional dianggap sebagai determinan paling kuat untuk mempromosikan perilaku inovatif karyawan di tempat kerja (Jong \& Hartog, 2007). Penerapan gaya kepemimpianan yang transformatif akan mendorong karyawan menjadi lebih inovatif (Günzel-Jensen, Hansen, Jakobsen, \& Wulff, 2018; Hansen \& Pihlthingvad, 2019; Kresnandito, 2012; Pieterse, Knippenberg, Schippers, \& Stam, 2010).

H1: Diduga kepemimpinan transformasional berpengaruh signifikan positif terhadap perilaku inovatif.

Knowledge sharing menjadi salah satu determian yang dominan dalam membangun perilaku inovatif karyawan (Denti \& Hemlin, 2012; Mura et al., 2013; Rahmahthia \& Etikariena, 2019). Melalui kegiatan knowledge sharing, anggota organisasi dapat bertukar informasi serta pengalaman kerja yang mampu memunculkan lahirnya ide-ide baru yang selanjutnya ide tersebut menjadi inovasi organisasi (Mura et al., 2013). Lebih jauh lagi, proses knowledge sharing mampu mendorong angggota organisasi untuk melakukan penciptaan peluang sebagai upaya untuk menghasilkan solusi serta efisiensi (Widodo, 2013). Gambar 1 menunjukkan hubungan antar variabel dalam penelitian ini.

H2: Diduga knowledge sharing berpengaruh signifikan positif terhadap perilaku inovatif.

\section{METODE PENELITIAN}

Penelitian ini menggunakan metode penelitian kuantitatif. Dimensi kepemimpinan trasnformasional yaitu idealized influence, inspirational motivation, intellectual stimulation, dan individuallized consideration (Bass \& Riggio, 2006). Dimensi variabel knowledge sharing yaitu knowledge donating dan knowlede collecting (De Vries et al., 2006). Dimensi perilaku inovatif yaitu idea exploration, idea generation, idea championing, dan idea implementation (Jong \& Hartog, 2010). Populasi dalam 
penelitian ini adalah dosen pada 3 universitas yang ada di Kota Cirebon yaitu Universitas Swadaya Gunung Jati, Universitas Muhammadiyah Cirebon, dan Universitas Nahdatul Ulama Cirebon dengan jumlah 624 orang. Pengukuran jumlah sampel menggunakan rumus Slovin dengan margin of error $10 \%$ sehingga ditetapkan jumlah sampel sebanyak 86 responden. Data dikumpulkan melalui kuesioner dengan menggunakan skala Likert. Analisis data dalam penelitian ini menggunakan Regresi Berganda. Tahapan analisis data diawali dengan uji validitas dan reliabilitas instrumen, uji asumsi klasik, selanjutnya analisis korelasi dan determinasi serta terakhir adalah pengujian hipotesis.

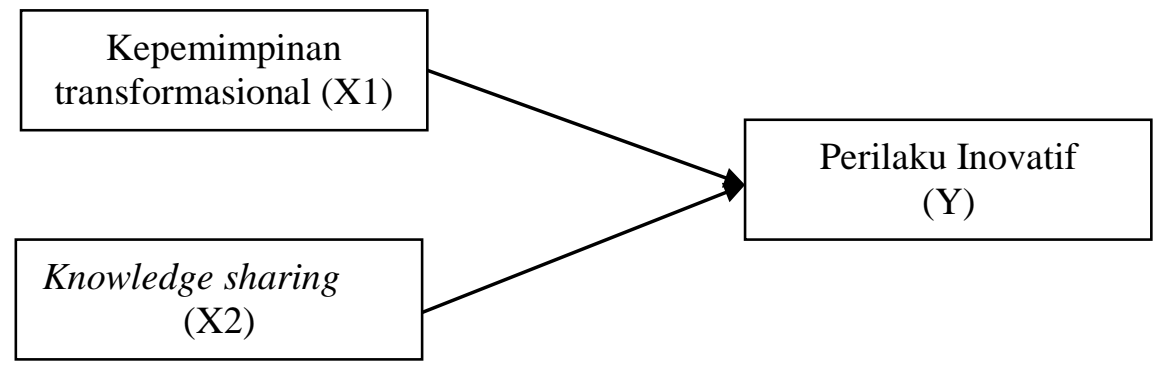

Gambar 1. Kerangka Konseptual

\section{HASIL DAN PEMBAHASAN}

\section{Hasil Uji Validitas dan Validitas}

Tahapan analisis data yang pertama dalam penelitian ini adalah pengujian validitas instrumen. Hasil pengujian validitas instrumen ditampilkan dalam Lampiran 1. Hasil pengujian validitas menunjukkan bahwa seluruh instrumen dalam variabel kepemimpinan transformasional, knowledge sharing, dan perilaku inovatif adalah valid karena nilai $r$ hitung (di atas) $>0,203$. Selanjutnya, hasil uji reliabilitas instrumen ditampilkan dalam Lampiran 2. Hasil uji reliabilitas menunjukkan bahwa variabel kepemimpinan transformasional, knowledge sharing, dan perilaku inovatif adalah reliabel karena nilai Cronbach's Alpha (di atas) $>0,7$.

\section{Hasil Uji Asumsi Klasik}

Tahapan analisis data selanjutnya adalah melakukan uji asumsi klasik. Terdapat 4 hasil uji asumsi klasik di antaranya adalah hasil uji normalitas, multikolinearitas, autokorelasi, dan heteroskedastisitas. Hasil uji normalitas menunjukkan bahwa nilai Asymp. Sig. (2-tailed) adalah 0.339 lebih besar dari 0,05. Berdasarkan nilai tersebut, data berdistribusi normal. Hasil uji multikolinearitas menunjukkan bahwa nilai VIF variabel kepemimpinan transformasional dan knowledge sharing adalah 1.213 lebih kecil dari 10,00. Hasil pengujian tersebut menunjukkan bahwa tidak terjadi gejala multikolinieritas dalam model regresi. Hasil uji autokorelasi menujukan bahwa nilai Durbin-Watson sebesar 1.898 lebih besar dari batas atas (dU) yaitu 1.696. Hasil ini menujukkan bahwa dalam analisis data tidak terjadi autokorelasi dan analisis regresi ganda dapat dilanjutkan. Hasil uji heteroskedastisitas menunjukkan bahwa nilai Sig variabel kepemimpinan transformasional dan knowledge sharing adalah 0,153 dan 0,510. Nilai tersebut lebih besar dari standar 0,05 , sehingga tidak terjadi gejala heteroskedastisitas dalam model regresi dalam penelitian ini. Hasil uji asumsi klasik selengkapnya dapat dilihat di Lampiran 3-6.

\section{Hasil Uji Korelasi}

Hasil pengukuran koefisien korelasi dan determinasi variabel kepemimpian transformasional dan knowledge sharing terhadap perilaku inovatif dapat diketahui pada Tabel 1. Hasil pengujian yang terdapat pada Tabel 1 menujukkan bahwa nilai koefisien korelasi (R) variabel kepemimpinan transformasional dan knowledge sharing terhadap perilaku inovatif adalah 0,723. Nilai ini memiliki makna bahwa derajat keeratan hubungan antara variabel kepemimpinan transformasional dan knowledge sharing terhadap perilaku inovatif termasuk pada kategori kuat. Nilai koefisien determinasi (Adjusted $R$ Square) variabel kepemimpinan transformasional serta knowledge sharing terhadap perilaku inovatif adalah 0,511. Nilai ini memiliki makna bahwa pengaruh variabel kepemimpian transformasional dan knowledge sharing terhadap perilaku inovatif sebesar $51,1 \%$. 
Agi Syarif Hidayat \& Rofi Rofaida. Peran Kepemimpinan Transformasional dan Knowledge Sharing dalam Menstimulasi Perilaku Inovatif di Institusi Pendidikan

Tabel 1.

MODEL SUMMARY

\begin{tabular}{ccccc}
\hline Model & $\mathbf{R}$ & $\boldsymbol{R}$ Square & Adjusted $\boldsymbol{R}$ Square & Std. Error of the Estimate \\
\hline 1 & $.723^{\mathrm{a}}$ & .522 & .511 & 4.22001 \\
\hline
\end{tabular}

Sumber: Data diolah (2019)

\section{Hasil Uji Anova}

Hasil pengukuran signifikansi pengaruh kepemimpian trasnformasional dan knowledge sharing terhadap perilaku inovatif secara simultan, dapat dilihat dalam Tabel 2. Hasil pengujian yang ditampilkan dalam Tabel 2 menujukkan bahwa nilai $\mathrm{F}$ statistik adalah 45.411> 3.110. Hipotesis Anova dapat diterima bahwa semua variabel independen yaitu kepemimpinan transformasional dan knowledge sharing layak untuk menjelaskan variabel perilaku inovatif.

Tabel 2.

HASIL UJI ANOVA

\begin{tabular}{llccccc}
\hline & Model & Sum of Squares & df & Mean Square & F & Sig. \\
\hline 1 & Regression & 1617.394 & 2 & 808.697 & 45.411 & $.000^{\mathrm{a}}$ \\
& Residual & 1478.106 & 83 & 17.809 & & \\
& Total & 3095.500 & 85 & & & \\
\hline
\end{tabular}

Sumber: Data diolah (2019)

\section{Hasil Uji Hipotesis}

Pengujian hipotesis dalam penelitian ini ditampilkan dalam Tabel 3. Hasil pengujian hipotesis pada Tabel 3 menujukkan bahwa nilai T Statistik kepemimpinan transformasional adalah 3.892>1.662. Hal ini memiliki arti bahwa kepemimpinan transformasional berpengaruh signifikan dan positif terhadap perilaku inovatif. Nilai T Statistik knowledge sharing adalah 6.270>1.662. Hal ini menujukkan bahwa knowledge sharing berpengaruh signifikan dan positif terhadap perilaku inovatif.

Tabel 3.

\section{HASIL UJI HIPOTESIS}

\begin{tabular}{|c|c|c|c|c|c|c|}
\hline & \multirow[t]{2}{*}{ Model } & \multicolumn{2}{|c|}{ Unstandardized Coefficients } & \multirow{2}{*}{$\begin{array}{c}\text { Standardized } \\
\text { Coefficients } \\
\text { Beta } \\
\end{array}$} & \multirow[t]{2}{*}{$\mathbf{t}$} & \multirow[t]{2}{*}{ Sig. } \\
\hline & & B & Std. Error & & & \\
\hline \multirow[t]{3}{*}{1} & (Constant) & 6.637 & 3.068 & & 2.164 & .033 \\
\hline & Transformational leadership & .261 & .067 & .325 & 3.892 & .000 \\
\hline & Knowledge sharing & .664 & .106 & .524 & 6.270 & .000 \\
\hline
\end{tabular}

Sumber: Data diolah (2019)

\section{Pengaruh Kepemimpinan Transformasional terhadap Perilaku Inovatif}

Hasil pengujian hipotesis pertama menujukkan bahwa perilaku inovatif dipengaruhi secara signifikan oleh variabel kepemimpinan transformasional. Temuan penelitian ini memiliki makna bahwa penerapan gaya kepemimpinan transformasional akan mendorong peningkatan perilaku inovatif karyawan. Temuan penelitian ini sejalan dan semakin memperkuat temuan penelitian sebelumnya terkait kepemimpinan transformasional serta perilaku inovatif (Günzel-Jensen et al., 2018; Hansen \& Pihl-thingvad, 2019; Weng, Huang, Chen, \& Chang, 2015).

Salah satu dimensi kepemimpinan transformasional yang sangat berkaitan dengan perilaku inovatif adalah intelectual stimulation. Intelectual stimulation merupakan karakter pemimpin yang mampu mendorong bawahan untuk berfikir secara kreatif, mengarahkan bawahan untuk memecahkan 
permasalahan dengan pendekatan baru atau berbeda serta menantang para bawahan untuk melakukan inovasi. Karakter pemimpin seperti ini sangat dibutuhkan dalam membangun organisasi yang inovatif.

Pada penelitian ini pengaruh kepemimpinan transformasional lebih rendah apabila dibandingkan dengan knowledge sharing. Ini menjadi temuan yang menarik, untuk penelitian selanjutnya dapat digunakan variabel moderasi untuk memperkuat hubungan antara kepemimpinan transformasional terhadap perilaku inovatif. Salah satu variabel moderasi yang dapat digunakan adalah psycological empowerment atau pemberdayaan psikologis. Pemberdayaan psikologis adalah keadaan psikologis yang berada di dalam individu, yang mencerminkan orientasi aktif menuju peran kerja. Temuan penelitian Pieterse et al., (2010) menunjukkan bahwa kepemimpinan transfomasional memliki pengaruh yang lebih besar dan signfikan ketika dimediasi oleh variabel psyological empowerment.

\section{Pengaruh Knowledge Sharing terhadap Perilaku Inovatif}

Hasil pengujian hipotesis yang kedua menujukkan bahwa knowledge sharing memiliki pengaruh positif dan signifikan terhadap perilaku inovatif. Temuan penelitian ini memiliki makna bahwa dengan semakin meningkatkan intensitas knowdeg sharing maka mendorong peningkatan perilaku inovatif karyawan. Temuan penelitian ini sejalan dan semakin memperkuat temuan penelitian sebelumnya terkait peran knowledge sharing dalam menstimulasi perilaku inovatif (Kang \& Lee, 2017; Mura et al., 2013; Rahmahthia \& Etikariena, 2019)

Terdapat beberapa alasan kenapa knowledge sharing memiliki pengaruh yang dominan yaitu: (1) melalui pelaksanaan knowledge sharing, anggota organisasi dapat melakukan pertukaran ide atau pengetahuan baru yang memungkinkan mereka menemukan banyak peluang untuk melaksanakan inovasi untuk organisasi; (2) melalui pelaksanaan knowledge sharing, anggota organisasi mendapatkan banyak informasi penting dari rekan yang dapat digunakan untuk membuat gagasan inovasi yang baru; (3) melalui knowledge sharing, anggota organisasi memiliki ruang untuk mengenalkan gagasan inovasi merka serta menemukan komunitas untuk menyampaikan gagasan inovasi mereka; (4) melalui knowledge sharing, anggota organisasi memiliki keberanian untuk mengimplementasikan ide-ide inovasi mereka karena memiliki partner dalam pelaksanaan inovasi tersedia yang mereka dapatkan dalam proses knowledge sharing.

Knowledge sharing sepertinya hal yang gampang, tapi dalam pelaksanaanya tidak mudah karena tidak semua karyawan mau membagikan pengetahuannya dan tidak semua orang juga memiliki motivasi untuk menggali informasi atau pengetahuan dari rekan kerjanya. Organisasi perlu mendukung pelaksanaan knowledge sharing melalui penyedian ruangan, bahkan apabila diperlukan adanya pemberian reward bagi orang orang yang melakukaan donasi pengetahuan, hal ini penting karena dengan adanya donasi pengetahun maka pengetahuan akan lebih mudah didapatkan dengan biaya yang lebih murah dan akan sangat membantu organisasi dalam melakukan efektifitas dan efisiensi pengembangan sumber daya manusia.

Salah satu temuan penting penelitian ini adalah kontribusi knowledge sharing yang lebih besar dalam mendorong peningkatan perilaku inovatif karyawan. Hal ini menarik karena untuk mendorong karyawan menjadi lebih inovatif tidak hanya dilakukan dengan pendekatan top down oleh pimpinan tetapi juga bisa melalui pendekatan bottom up yaitu dari anggota organisasi. Organisasi perlu untuk merekrut karyawan yang potensial dan memiliki kompetensi yang tinggi sehingga ada banyak pengetahuan yang diberikan. Di samping itu, pemimpin harus mampu memotivasi bawahan untuk mau untuk belajar hal-hal baru kepada rekan kerja mereka. Sekali lagi knowledge sharing membuat pengetahuan yang ada dalam organisasi menjadi lebih bernilai karena tidak hanyak dimiliki oleh satu orang tetapi bisa dimiliki oleh anggota organisasi lainnya.

\section{KESIMPULAN}

Berdasarkan hasil penelitian dapat disimpulkan bahwa kepemimpinan transformasional dan knowledge sharing memiliki pengaruh signifikan dan positif terhadap terhadap perilaku inovatif. Knowledge sharing memiliki pengaruh yang lebih besar dibandingkan kepemimpinan 
Agi Syarif Hidayat \& Rofi Rofaida. Peran Kepemimpinan Transformasional dan Knowledge Sharing dalam Menstimulasi Perilaku Inovatif di Institusi Pendidikan

tranasformasional untuk membangun perilaku inovatif. Implikasi manajerial berdasarkan kesimpulan penelitian ini adalah perlunya organisasi untuk memfasilitasi proses knowlede sharing baik dari aspek fasilitas maupun kebijakan. Selain itu, bagi para pimpian dari setiap level penting untuk menerapkan gaya kepemimpinan transformasional sebagai upaya untuk menstimulasi perilaku inovatif karyawan. Penelitian ini baru menguji variabel kepemimpinan transformasional dan knowledge sharing sebagai determinan perilaku inovatif, padahal masih terdapat beberapa variabel yang dapat digunakan sebagai determinan perilaku inovatif. Penelitian selanjutnya dapat menguji pengaruh kepemimpinan transaksional sebagai salah satu alternatif determinan perilaku inovatif. Selain itu, untuk peneliti selanjutnya disarankan melakukan penelitian dengan jumlah sampel yang lebih banyak yaitu di atas 100 responden dengan menggunakan teknik analisis data yang lebih mutakhir seperti structural equation model.

\section{DAFTAR PUSTAKA}

Avolio, B. J., \& Bass, B. M. (1995). Individual consideration viewed at multiple levels of analysis: A multi-level framework for examining the diffusion of transformational leadership. The Leadership Quarterly, 6(2), 199-218. https://doi.org/https://doi.org/10.1016/10489843(95)90035-7.

Bass, B. M., \& Riggio, R. E. (2006). Transformational Leadership Second Edition. London: Lawrence Erlbaum Associates, Publishers.

Bass, B. M., Waldman, D. A., \& Avolio, B. J. (1987). Transformational leadership and the falling dominoes effect. Group \& Organization Studies, 12(1), 73-87. https://doi.org/https://doi.org/10.1177/105960118701200106.

Bos-nehles, A. C., \& Veenendaal, A. A. R. (2019). Perceptions of HR practices and innovative work behavior: the moderating effect of an innovative climate. The International Journal of Human Resource Management, 30(18), 2661-2683. The International Journal of Human Resource Management, 30(18), 1-23. https://doi.org/10.1080/09585192.2017.1380680.

Chen, Y., Tang, G., Jin, J., Xie, Q., \& Li, J. (2014). CEO s' transformational leadership and product innovation performance: The roles of corporate entrepreneurship and technology orientation. Journal of Product Innovation Management, 31, 2-17. https://doi.org/10.1111/jpim.12188.

De Vries, R. E., Van den Hooff, B., \& De Ridder, J. A. (2006). Explaining knowledge sharing: The role of team communication styles, job satisfaction, and performance beliefs. Communication Research, 33(2), 115-135. https://doi.org/10.1177/0093650205285366.

Denti, L., \& Hemlin, S. (2012). Leadership and innovation in organizations: a systematic review of factors that mediate or moderate the relationship. International Journal of Innovation Management, 16(3), 1-20. https://doi.org/10.1142/S1363919612400075.

Dewanto, W., \& Fasial, M. (2017). Manajemen INovasi. Bandung: Alfabeta.

Dvir, T., Eden, D., Avolio, B. J., \& Shamir, B. (2002). Impact of transformational leadership on follower development and performance: A field experiment. Academy of Management Journal, 45(4), 735-744. https://doi.org/10.2307/3069307.

Dyer, J., Gregersen, H., \& Christensen, C. M. (2011). The innovator's DNA: Mastering the five skills of disruptive innovators. Harvard Business Press.

Günzel-Jensen, F., Hansen, J. R., Jakobsen, M. L. F., \& Wulff, J. (2018). A two-pronged approach? Combined leadership styles and innovative behavior. International Journal of Public Administration, 41(12), 957-970. https://doi.org/10.1080/01900692.2017.1303711.

Hansen, J. A., \& Pihl-thingvad, S. (2019). Managing employee innovative behaviour through 
transformational and transactional leadership styles. Public Management Review, 21(6), 918944. https://doi.org/10.1080/14719037.2018.1544272.

Jaberi, E. (2016). The effect of knowledge sharing on innovative behavior among employee of Besat hospital in city of Hamedan. International Academic Journal of Accounting and Financial Management, 3(4), 41-47.

Jong, J. de, \& Hartog, deanne den. (2007). How leaders influence employees' innovative behaviour. European Journal of Innovation Management, 10(1), 41-64. https://doi.org/10.1108/14601060710720546.

Jong, J. De, \& Hartog, D. den. (2010). Measuring innovative work behaviour. Creativity and Innovation Management, 19(1), 23-36. https://doi.org/10.1111/j.1467-8691.2010.00547.x.

Kang, M., \& Lee, M. J. (2017). Absorptive capacity, knowledge sharing, and innovative behaviour of R\&D employees. Technology Analysis \& Strategic Management, 29(2), 219-232. https://doi.org/10.1080/09537325.2016.1211265.

Khodakarami, P., \& Zakaria, Z. (2015). The Relationship between Innovative Behavior and Sustainable Development. European Journal of Business and Management, 7(23), 160-169.

Kleysen, R. F., \& Street, C. T. (2011). Toward a multi-dimensional measure of individual innovative behavior. Journal of Intellectual Capital, 2(3), 284-296. https://doi.org/https://doi.org/10.1108/EUM0000000005660.

Kresnandito, A. P. (2012). Pengaruh Persepsi Kepemimpinan Transformasional terhadap Perilaku Inovatif Penyiar Radio. Jurnal Psikologi Industri Dan Organisasi, 1(02), 96-103.

Lee, H. S., \& Hong, S. A. (2014). Factors Affecting Hospital Employees ' Knowledge Sharing Intention and Behavior, and Innovation Behavior. Osong Public Health and Research Perspectives, 5(3), 148-155. https://doi.org/10.1016/j.phrp.2014.04.006.

Leong, C. T., \& Rasli, A. (2014). The Relationship between Innovative Work Behavior on Work Role Performance: An Empirical Study. Procedia - Social and Behavioral Sciences, 129(November), 592-600. https://doi.org/10.1016/j.sbspro.2014.03.717.

Lin, H. F. (2007). Knowledge sharing and firm innovation capability: an empirical study. International Journal of Manpower, 28(3), 315-332. https://doi.org/10.1108/01437720710755272.

Muhtarom, A. (2015). Implementasi Manajemen Sumber Daya Manusia Dalam Peningkatan Profesionalitas Dosen Perguruan Tinggi Agama Islam Provinsi Banten. Tarbawi, 1(2), 117130.

Muliawaty, L. (2019). Peluang Dan Tantangan Sumber Daya Manusia Di Era Disrupsi. Kebijakan : Jurnal Ilmu Administrasi, 10(1), 1. https://doi.org/10.23969/kebijakan.v10i1.1416.

Mura, M., Lettieri, E., Radaelli, G., \& Spiller, N. (2013). Promoting professionals' innovative behaviour through knowledge sharing: the moderating role of social capital. Journal of Knowledge Management, 17(4), 527-544.

Nurjanah, S. (2015). Peranan manajemen inovasi dalam meningkatkan kinerja organisasi pendidikan. In Conference In Business, Accounting, And Management (CBAM) (pp. 27-33).

Orces, S. O. S. F., Kim, Y., \& Lee, J. (2005). Behavioral Intention Formation In Knowledge Sharing: Examining The Roles Of Extrinsic Motivators, Social-Psychological Forces, And Organizational Climate. MIS Quarterly, 29(1), 87-111. 
Agi Syarif Hidayat \& Rofi Rofaida. Peran Kepemimpinan Transformasional dan Knowledge Sharing dalam Menstimulasi Perilaku Inovatif di Institusi Pendidikan

Pieterse, A. N., Knippenberg, D. V. A. N., Schippers, M., \& Stam, D. (2010). Transformational and transactional leadership and innovative behavior: The moderating role of psychological empowerment. Journal of Organizational Behavior, 31(4), 609-623. https://doi.org/10.1002/job.

Rahmahthia, S. E., \& Etikariena, A. (2019). Pengaruh Knowledge Sharing Behavior terhadap Perilaku Inovatif di Tempat Kerja pada Karyawan PT X dan PT Y The Effect of Knowledge Sharing Behavior on Innovative Work Behavior among Employee at. Jurnal Psikogenesis, 7(2), 116128.

Taherparvar, N., Esmaeilpour, R., \& Dostar, M. (2014). Customer knowledge management, innovation capability and business performance: a case study of the banking industry. Journal of Knowledge Management, 18(3), 591-610. https://doi.org/10.1108/JKM-11-2013-0446.

Weng, R. H., Huang, C. Y., Chen, L. M., \& Chang, L. Y. (2015). Exploring the impact of transformational leadership on nurse innovation behaviour: A cross-sectional study. Journal of Nursing Management, 23(4), 427-439. https://doi.org/10.1111/jonm.12149.

Widodo. (2013). Peran Knowledge Sharing Terhadap Kinerja UKM Berbasis Sikap Kewirausahaan. EKOBIS, 14(2), 17-27.

Yuan, F., \& Woodman, R. W. (2010). Innovative Behavior In The Workplace: The Role Of Performance And Image Outcome Expectations The University of Kansas Performance And Image. Academy of Management Journal, 53(2), 323-342. https://doi.org/https://doi.org/10.5465/AMJ.2010.49388995. 


\section{Lampiran 1. HASIL UJI VALIDITAS}

\begin{tabular}{|c|c|c|c|}
\hline Instrumen & R Hitung & R Tabel & Keterangan \\
\hline TL1 & .713 & .203 & Valid \\
\hline TL2 & .600 & .203 & Valid \\
\hline TL3 & .806 & .203 & Valid \\
\hline TL4 & .517 & .203 & Valid \\
\hline TL5 & .790 & .203 & Valid \\
\hline TL6 & .792 & .203 & Valid \\
\hline TL7 & .766 & .203 & Valid \\
\hline TL8 & .694 & .203 & Valid \\
\hline TL9 & .659 & .203 & Valid \\
\hline TL10 & .560 & .203 & Valid \\
\hline TL11 & .734 & .203 & Valid \\
\hline KS1 & .642 & .203 & Valid \\
\hline KS2 & .712 & .203 & Valid \\
\hline $\mathrm{KS} 3$ & .648 & .203 & Valid \\
\hline KS4 & .546 & .203 & Valid \\
\hline KS5 & .700 & .203 & Valid \\
\hline KS6 & .393 & .203 & Valid \\
\hline KS7 & .583 & .203 & Valid \\
\hline KS8 & .596 & .203 & Valid \\
\hline IB1 & .347 & .203 & Valid \\
\hline IB2 & .560 & .203 & Valid \\
\hline IB3 & .614 & .203 & Valid \\
\hline IB4 & .589 & .203 & Valid \\
\hline IB5 & .553 & .203 & Valid \\
\hline IB6 & .737 & .203 & Valid \\
\hline IB7 & .778 & .203 & Valid \\
\hline IB8 & .740 & .203 & Valid \\
\hline IB9 & .632 & .203 & Valid \\
\hline IB 10 & .669 & .203 & Valid \\
\hline
\end{tabular}

Sumber: Data diolah (2019)

\section{Lampiran 2. HASIL UJI RELIABILITAS}

\begin{tabular}{lccc}
\hline Nama Variabel & Cronbach's Alpha & $\begin{array}{c}\text { Cronbach's Alpha Based on } \\
\text { Standardized Items }\end{array}$ & N of Items \\
\hline $\begin{array}{l}\text { Kepemimpinan } \\
\text { transformasional }\end{array}$ & .923 & .924 & 11 \\
Knowledge sharing & .852 & & \\
Perilaku inovatif & .884 & .860 & 8 \\
\hline
\end{tabular}

Sumber: Data diolah (2019)

\section{Lampiran 3. HASIL UJI NORMALITAS}

\begin{tabular}{llr}
\hline \multicolumn{1}{c}{ Parameter } & Unstandardized Residual \\
\hline $\mathrm{N}$ & & 86 \\
Normal Parameters $^{a}$ & Mean & .0000000 \\
& Std. Deviation & 4.17006945 \\
Most Extreme Differences Absolute & .101 \\
& Positive & .101 \\
& Negative & -.065 \\
Kolmogorov-Smirnov Z & & .940 \\
Asymp. Sig. (2-tailed) & .339 \\
\hline
\end{tabular}

Sumber: Data diolah (2019) 
Agi Syarif Hidayat \& Rofi Rofaida. Peran Kepemimpinan Transformasional dan Knowledge Sharing dalam Menstimulasi Perilaku Inovatif di Institusi Pendidikan

Lampiran 4. HASIL UJI MULTIKOLINIERITAS

\begin{tabular}{|c|c|c|c|c|c|c|c|}
\hline & \multicolumn{2}{|c|}{$\begin{array}{c}\text { Unstandardized } \\
\text { Coefficients }\end{array}$} & \multirow{2}{*}{$\begin{array}{c}\text { Standardized } \\
\text { Coefficients } \\
\text { Beta }\end{array}$} & \multirow{2}{*}{ 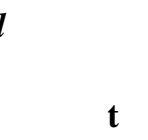 } & \multirow[b]{2}{*}{ Sig. } & \multicolumn{2}{|c|}{$\begin{array}{c}\text { Collinearity } \\
\text { Statistics }\end{array}$} \\
\hline & B & Std. Error & & & & Tolerance & VIF \\
\hline (Constant) & 6.637 & 3.068 & & 2.164 & .033 & & \\
\hline $\begin{array}{l}\text { Kepemimpinan } \\
\text { Transformasional }\end{array}$ & .261 & .067 & & .3253 .892 & .000 & .825 & 1.213 \\
\hline Knowledge Sharing & .664 & .106 & & .5246 .270 & .000 & .825 & 1.213 \\
\hline
\end{tabular}

Sumber: Data diolah (2019)

Lampiran 5. HASIL UJI AUTOKORELASI

\begin{tabular}{|c|c|c|c|c|c|}
\hline Model & $\mathbf{R}$ & $R$ Square & Adjusted R Square & $\begin{array}{l}\text { Std. Error of the } \\
\text { Estimate }\end{array}$ & Durbin-Watson \\
\hline 1 & $.723^{\mathrm{a}}$ & .522 & .511 & 4.22001 & 1.898 \\
\hline
\end{tabular}

Sumber: Data diolah (2019)

Lampiran 6. HASIL UJI HETEROSKEDASTISITAS

\begin{tabular}{|c|c|c|c|c|c|}
\hline \multirow{2}{*}{ Model } & \multicolumn{2}{|c|}{ Unstandardized Coefficients } & \multirow{2}{*}{$\begin{array}{c}\text { Standardized Coefficients } \\
\text { Beta }\end{array}$} & \multirow{2}{*}{$\mathbf{t}$} & \multirow{2}{*}{ Sig. } \\
\hline & B & Std. Error & & & \\
\hline (Constant) & 6.639 & 1.939 & & 3.424 & .001 \\
\hline Kepemimpinan Transformasional & -.061 & .042 & -.170 & -1.443 & .153 \\
\hline Knowledge Sharing & -.044 & .067 & -.078 & -.662 & .510 \\
\hline
\end{tabular}

Sumber: Data diolah (2019) 